\title{
A qualitative assessment tool for innovative waste logistics scenarios: a case study for Flanders
}

\author{
Jeffrey Willems ${ }^{1 *}\left(\mathbb{D}\right.$, Tom Pauwels ${ }^{2}$, Edwin van Hassel ${ }^{1}$, Thierry Vanelslander ${ }^{1}$ and Steve Sel ${ }^{3}$
}

\section{${ }^{*}$ Correspondence:}

Jeffrey.willems@uantwerpen

be

${ }^{1}$ University of Antwerp, Prinsstraat 13,

2000 Antwerpen, Belgium Full list of author information is available at the end of the article

\begin{abstract}
With new, innovative logistics tools and frameworks coming to the market rather quickly, developing a decision support framework to assess its value before carrying out extensive, quantitative economic assessment studies and large-scale implementation is necessary. This paper focuses on developing a qualitative decision support framework - aiding the deployment of successful tools in the logistics landscape and avoiding high sunk costs without added value. Resulting in a qualitative tool based on a literature review and industry expert interviews. The derived parameter impact model assesses the importance of different parameters, allowing to find opportunities without the need for extensive information and/or investments. Therefore, the parameter impact model was applied to three different cases of waste logistics located in Flanders: (1) the use of telemetry (i.e., the use of sensors to identify the filling rate of waste collection points remotely), (2) small waste compactors on the business side, and (3) inland waterways to transport waste to treatment centers. The qualitative results can vary depending on the specific case, establishing the fundament for future innovations.
\end{abstract}

Keywords: Waste logistics, Decision support tool, Parameter impact model, Reverse logistics

\section{Introduction}

There is a scarcity of primary raw materials and its associated energy needs leading to rising and volatile prices on the world market (Milios et al. 2019). However, secondary material flows are not being optimally used today, and we, as a consumer society, are throwing away products at the end of its life cycle-i.e. so-called linear production and consumption. The challenge lies in evolving into a sustainable and circular production and consumption process. Products would not just be thrown away but instead recycled or reused within specific production processes. Its rollout implies that products/waste must be collected to maximize the recovery of raw materials. Although these product life expansion initiatives contain good ideas, the various stakeholders within the supply chain need to be aligned (Milios et al. 2019). Ultimately, society aims to evolve into a circular economy in which no or as few goods

(c) The Author(s) 2022. Open Access This article is licensed under a Creative Commons Attribution 4.0 International License, which permits use, sharing, adaptation, distribution and reproduction in any medium or format, as long as you give appropriate credit to the original author(s) and the source, provide a link to the Creative Commons licence, and indicate if changes were made. The images or other third party material in this article are included in the article's Creative Commons licence, unless indicated otherwise in a credit line to the material. If material is not included in the article's Creative Commons licence and your intended use is not permitted by statutory regulation or exceeds the permitted use, you will need to obtain permission directly from the copyright holder. To view a copy of this licence, visit http:// creativecommons.org/licenses/by/4.0/. 


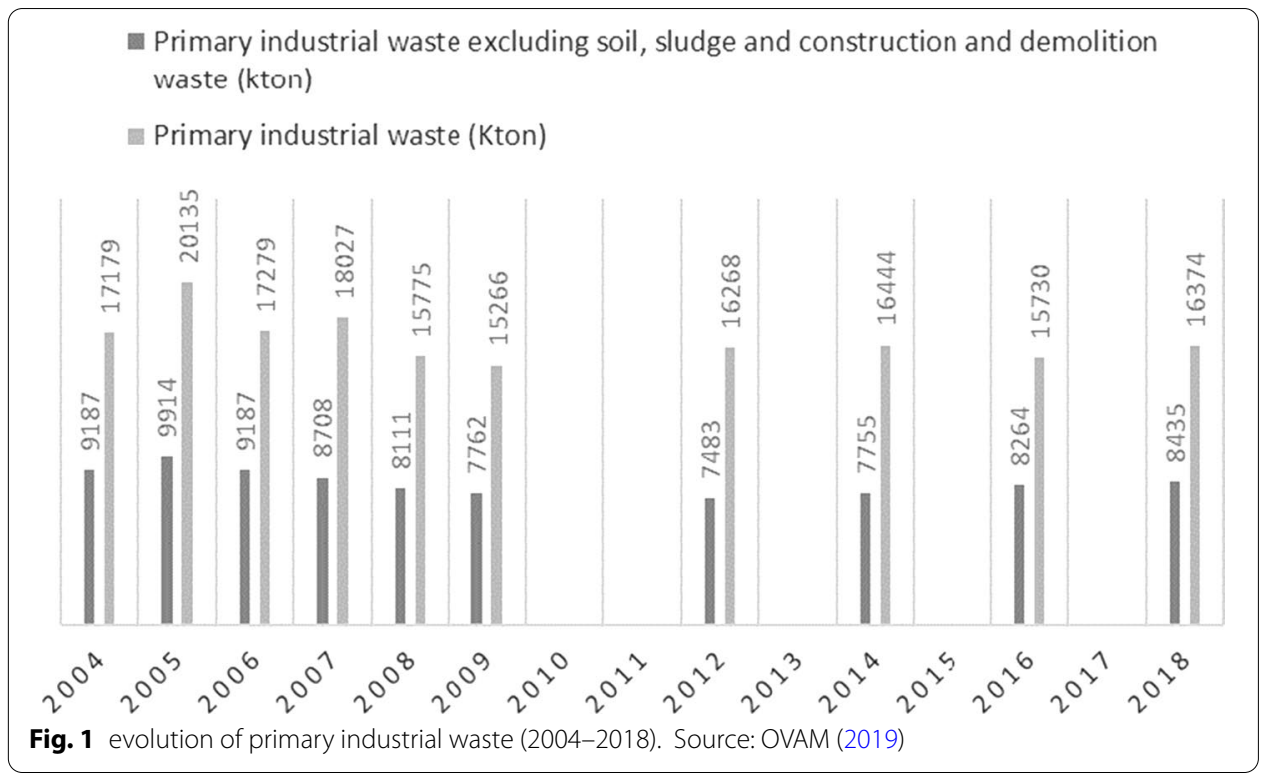

as possible find its way to an incinerator or landfills and can be used in the production process as secondary raw materials-leading to less waste and a cleaner planet.

Companies are increasingly aware of the problems surrounding waste and often no longer only operate from a business point of view. This business ethos is emphasized by the strategy that many companies already maintain today-Corporate Social Responsibility (CSR). These strategies attempt to maximize profits with the environment in mind, reflecting itself in the logistics involved in all the supply chain steps. Even though no attention used to be paid to goods that are located at the end of the life cycle, companies are increasingly paying attention to this phase. One reason may be the implementation of an extended producer responsibility (EPR) in which the producer is held partly responsible for the indirect waste the latter causes. A legislative framework can enforce EPR. Examples are product passports where the origin of the materials is tracked (van den Bergh 2020). Another reason may be that the goods produced are increasingly difficult to recycle. More and more, goods are optimized for (long-term) use. In order to achieve this, for example, different types of polyesters are woven with cotton in clothing to obtain the appropriate characteristics. Making recycling difficult due to the necessity to separate the different types of fabric that need a separate recycling program resulting in greater costs. (Visser 2018; VIL 2020).

What becomes clear from Fig. 1 is that the number of kilotons of waste produced by Flemish companies has remained more or less constant over time. The three R's-Reuse, Recycle, Reduce-can influence the amount of waste produced on the one hand and the recycling of the waste produced on the other (Seroka-Stolka and Ociepa-Kubicka 2018). Figure 2 shows how the industrial waste in Flanders is processed. Only a relatively small proportion $(4 \%)$ of all waste is incinerated directly. Nevertheless, 10 percent of all waste is incinerated after certain pre-treatments and other processes. In addition, 9 percent is deposited (i.e. landfill), 13 percent further 


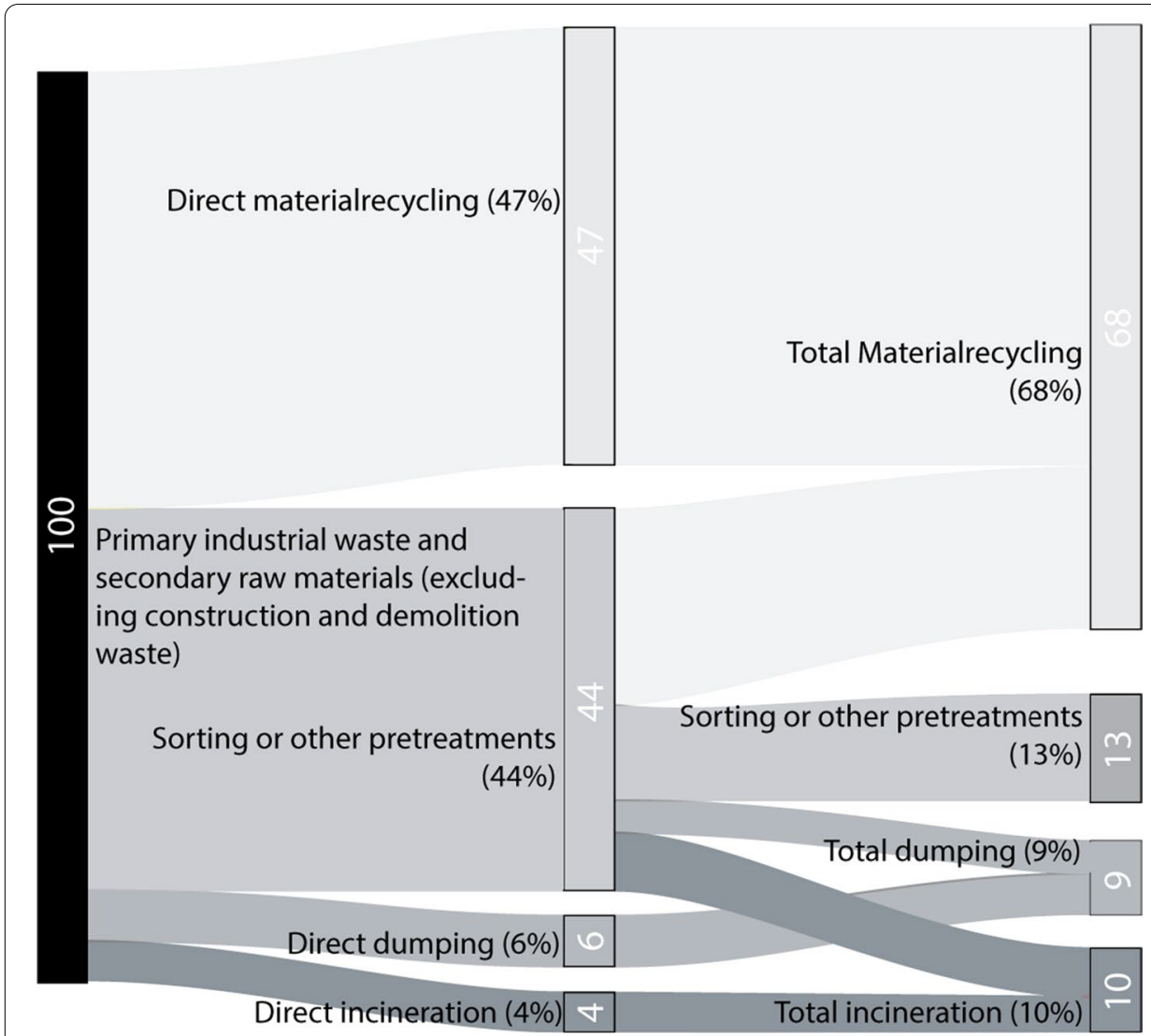

Fig. 2 Flowchart indicating the processing of primary industrial waste and secondary raw materials in Flanders. Source: OVAM (2019)

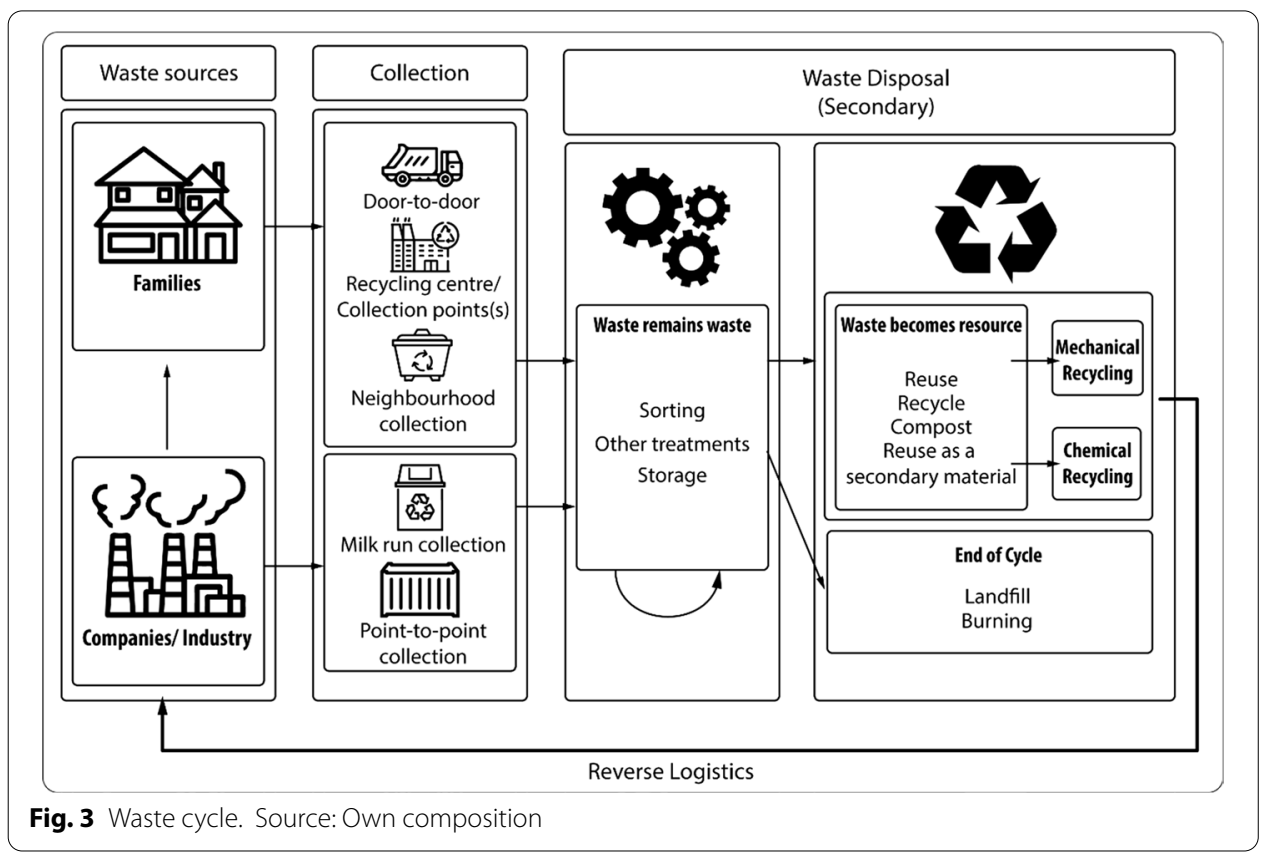


sorted and 68 percent recycled in different ways. Mapping out the processing capabilities and proportions in this way makes it possible to reflect to the potential of recycling in Flanders.

The purpose of this paper is to develop a qualitative model to assess new and alternative logistics supply chain solutions/applications for waste logistics with the emphasis on a sustainable environment. The goal is to optimize waste streams and induce less logistics flows and external cost while enabling efficient waste processing. Considering different waste streams like consumer household waste and industrial waste sources, a Parameter Impact (PI) model is drawn up based on expert interviews to qualitatively assess the different scenarios' relevance. The PI model is a decision-support framework to evaluate various waste logistics innovations without the need for extensive, quantitative information. Due to the frequent unavailability of data, using the PI model will allow to perform a quick scan of the specified scenario. If the result of this qualitative assessment is positive, the decision can be made to invest into collecting and analyzing application-specific data.

In this paper, the PI model will be applied to three scenarios: telemetry to forecast logistics planning, the usage of waste compactors to decrease the need for additional trips, and a modal shift toward inland waterways. To support these applications, different databases were consulted to understand better the current waste problem within Belgium and the current collection methods. The further structure of the paper is as follows: 2. Literature review 3. Methods 4. Applications of the framework 5. Conclusion 6. Discussion.

\section{Literature review}

The phase after the production and consumption process is sometimes called the extended logistics chain. Attention is paid not only to the so-called reverse logistics but also to its effects on the environment, people, and animals. The implementation of reverse logistics will affect the production and planning process, converting waste goods into products to meet consumer demand. (Suzanne et al. 2020). Companies are increasingly aware of the benefits that certain green measures bring and do not only participate from a marketing point of view (i.e. sometimes greenwashing ${ }^{1}$ ). Production companies, therefore, have the opportunity to source extra raw materials from ever more efficient recycling programs. In many cases, this additional supply of raw (secondary) materials results in increased availability. Residual materials can be defined according to Van Dyck (2008) as; (1) solids: by-products, waste; (2) liquids: emissions to water, liquid by-products; (3) gasses: emissions to air, gaseous by-products; and 4. residual heat. Cooperation has become a keyword in order to be able to reduce the costs of collecting the goods. In the case of textiles-that reach the end of their life cycle rather sporadically-home collection can be costly and ineffective. Alternatives are installing large collection containers that can be emptied weekly (Hole and Hole 2020). The role of logistics is to take on a proactive role within the green world and to think about various processes that can

\footnotetext{
${ }^{1}$ Greenwashing is the process of conveying a false impression or providing misleading information about how a company's products are more environmentally sound. Greenwashing is considered an unsubstantiated claim to deceive consumers into believing that a company's products are environmentally friendly. - Source: (Kenton \& James, 2021).
} 
contribute to making the industry sustainable, maximizing the recovery of various secondary materials-i.e. raw materials from waste.

Still, logistics and production companies use green as an attention-grabber and do not represent full commitment to their own sustainable goals. Various reasons can be: (1) the additional costs it entails compared to the linear way of working; (2) the additional investments to be made to collect, recycle and reuse the goods in the production process; (3) the uncertainty as to the quality of the goods that can be used; (4). the uncertainty regarding the delivery of goods (i.e. quantity over time). Gemoets (2021) cited this during an interview and questioned the continuity of the production and logistical process when completely switching to secondary goods. Therefore, Gemoets urged for a (short-term) future where the secondary material stream is complementary. According to industry experts, the preceding are all critical reasons, ensuring that a large number of companies active in the industry have not (yet) switched to secondary material flows to produce products. (Gelder 2021; Michail 2021; Quidousse 2021).

In the case of the waste sector, there are still opportunities for improvement. It is important to note that the vast majority of transport is done by road. The density of road transport opens up opportunities for more sustainable transport modes such as inland waterways and rail. However, there are barriers being inland waterway infrastructure and international rail regulations that make it inconvenient to transport goods-and in particular waste-internationally. In addition, the organization of recycling activities and production on a local scale can help reduce the number of empty kilometers to a minimum together with its associated emissions. Borbon-Galvez et al., (2021) define industrial symbiosis as the exchange of materials and energy between companies located near each other that have a different purpose for each other's materials. This can be partly determined by the life cycle assessment (LCA) and the material flow analysis (BorbonGalvez et al. 2021).

The waste cycle (Fig. 3) shows an overview of the different waste processes and also distinguishes among waste sources, collection methods, and waste treatment options. A distinction is made between two sources of waste-households, and businesses. Typical waste collection options are (1) home collection in connection with district collection (glass bulbs, collection boxes, Etc.) and (2) recycling centers. The collection of waste at businesses is often done via a milk round or a point-by-point collection. After collection, the waste disposal phase follows. A split is made between two different types of waste processing: 1. waste that remains waste: this can be sorted or; stored (i.e. landfill in most cases); 2 . waste that becomes raw material: waste can be recycled into secondary materials fit for use in different production processes through mechanical and/or chemical recycling.

Recycling waste can be done in two different ways. On the one hand, mechanical recycling is where waste goods are sent through a mechanical program/processing that divides the product into smaller parts, including basic raw materials. The raw materials can then be recovered by means of a process of rinsing, sorting, and extracting. This process must not affect the structure of polymers/raw materials. Circular goods that are eligible for mechanical recycling include plastics, metal, textiles, paper, tires, construction waste wood, and various other types of goods. On the other hand, chemical recycling can be implemented whereby waste undergoes a process in which the molecular 
chain is broken, forming a way of recycling. Clearly, it is stated that this is an additional procedure. For all plastics impossible to recycle mechanically, chemical recycling can be a solution to prevent landfill. (Bluevision sd; Zero waste Europe 2018; Emis sd; Plastics Europe sd).

Collecting textile waste for recycling is often still difficult, even though it is the second-largest polluting industry in the world. Still, only $13 \%$ of all textiles are recycled (compared to $73 \%$ of technological waste and $90 \%$ of glass waste) (Hole and Hole 2020). Several reasons are indicated by Hole \& Hole (2020) as the cause: (1) a lack of incentives that motivates the end user to recycle; (2) too few informational and educational programs; (3) collection opportunities are often expensive (i.e. door-to-door collection); (4) absence of a policy-most countries have no or few standards when it comes to recycling itself; (5) the variety of materials-it is apparent that many garments are made from different types of yarn, making it difficult and therefore also costly to split up the goods and eventually recycle them. Nevertheless, Matt Coz (VP recycle America) said, "if we don't make recycling convenient for the consumer, it's unlikely that we'll be successful". Therefore, certain prerequisites need to be considered to stimulate recycling from a governing point of view. First of all, research is required to determine the preferences regarding the frequency of collection from the system users. Hereby, the collection options should be adjusted accordingly. Second, in some cases, the waste collection is organized by a public company that historically grew into operating under the maximum efficiency potential-resulting in idle capacity and reducing economies of scale within that region. Thirdly, an assessment needs to be made on what to do with sparsely-populated areas (Gevaers et al. 2012).

A further gain can be made by using waste collection for eliminating empty trips. Empty return trips have a negative impact on the environment but also on the cost structure of a company. If empty return trips can be matched with waste collection, both internal and external costs are saved. For this to work, certain conditions need to be made up for different types of cargo (i.e. no contamination possibilities, etc.) - taking into account regulations for the transport of waste leading to a fragmented logistics market. So-called waste matching platforms can play an essential role in setting up return logistics networks. Platforms like Cyrkl, NISP, and Reloop can ensure that the supply and demand of secondary material flows complement each other to exchange goods. Cyrkl is a waste2resource marketplace that companies can join to sell secondary waste flows as a by-product from various production processes. Examples of secondary waste flows are; plastic granules, cardboard boxes, building material, and others (Cyrkl 2021). NISP was one of the first industrial symbiosis programs in the world and was introduced in 2007. The program found entry in more than 20 countries worldwide, providing training and consultancy services to improve sustainability (International synergies, sd). Reloop is a broad platform with a shared vision for a circular economy. The platform tries to bring together different stakeholders i.e. industry, government, NGO's to form a network. Enabling to create better conditions for circular raw materials flowing across the global economy, forming a catalyst to generate economic and environmental opportunities within the supply chain (Reloop 2020). OVAM, the Flemish Public Waste Agency, has launched a platform called symbioseplatform, where up until now, $200+$ residual waste streams are offered to exchange since its launch in 2019 (OVAM 2020). Therefore, 
manufacturers, their strategic partners, and network of suppliers cooperate and conduct business over the internet as part of an online marketplace. As a result, company costs decrease and revenue potentially increases together with participant productivity (Sathish and Jayaprakash 2017). From a logistics point of view, the logistics stakeholders have to be involved for transport to take place as efficiently as possible. Relating to the Corona pandemic, OVAM (2020) reported a significant rise by $65 \%$ in volume of highrisk medical waste. Organizing the disposal safely, alternative collection methods were used.

In many developing countries, waste management is held back by technically inefficient waste management systems, a lack of financial resources, and generally restricted public collaboration. As a result, waste management decision-making has become very complex, and picking intervention choices is often characterized by contradicting criteria. This necessitates the application of specialized decision-making tools. Even during planning, there is a need for accurate data on the features and flows of a specific area. This data is frequently incomplete, forming the primary barrier to corrective action planning. To overcome this, a qualitative decision support system can be implemented to assess the viability of different scenarios before investing into the collection of actionable data-i.e. a PI model. (Makarichi et al. 2018).

\section{Methods}

The methods used in this paper are rather inductive based on practical examples. The goal was to find out which type of transport is the most beneficial, considering the goods' nature and destination.

Desk research was used to give an overview of reverse logistics' limitations and opportunities as a precedent for the following analysis. Stakeholder workshops ${ }^{2}$ were set up to form the basis of the parameter impact model. During the first stakeholder workshop, the topic was jointly delineated and definitions aligned. The second workshop focused on waste flows from which specific lessons could be taken. Workshop 3 was used to judge the parameters to be used in the PI model, as collected from the desk research, as well as to start identifying use cases to which the PI model could be applied in our analysis. Workshop 4 was a final validation moment for the parameters, and was also used to determine the final set of use cases to which the PI model framework would be applied. The fifth and final workshop featured a discussion and validation of the use case PI application results. Both the desk research and the stakeholder workshops gave insights into the importance of different parameters within waste logistics and its correlating processes. In turn, these parameters form the fundaments to assess the implementation of the various applications within the (reverse) supply chain. Further elaboration on the specific applications can be found in Sect. 4.

\section{The framework: parameter impact (PI) model}

The aim of the Parameter Impact (PI) model is to qualitatively assess the impact that certain waste collection scenarios have in terms of (1) the logistics cost of the processes,

\footnotetext{
${ }^{2}$ See participants in Annex.
} 
(2) the waste processing outcome and (3) sustainability effects. The PI model can also be seen as a quick scan of a scenario before an extended business plan is worked out and serves as a framework to identify the most essential cost elements. It is clear that this is not a comprehensive model in which complex arithmetic calculations form the basis. Instead, it is a model that focuses on the relationships between the various observed parameters that play a role within the circular model. It allows getting rather fast qualitative insights into the waste logistics application. The next part explains the PI model's theoretical underpinnings and working methods. In the application section, the PI model is applied to three different cases. Four different steps can be distinguished in the process of building an individual PI model.

\section{Step 0: building the model: determination of the parameters that are important in waste logistics and the associated processes}

Based on a literature analysis, conversations with stakeholders, and user groups, a list of important parameters within waste logistics can be drawn up. These parameters can in turn be divided into three different categories, namely: 1 . the characteristics of the logistics activities, 2. the characteristics of the waste, 3. parameters that reflect environmental considerations and social awareness. These parameters can be qualitative and have an (in)direct effect on the logistics costs. Figure 4 shows all of these parameters, based on the previously mentioned sub-division:

\section{Step 1: description of the scenario to be investigated (e.g., pilot case)}

The first step defines the scenario to be investigated (i.e., the pilot case). A distinction is made between a reference scenario (H0) and the alternative scenario (H1). H0 describes the current situation (without the pilot case) and H1 represents the alternative (innovative) scenario (with pilot case). Meaning that the PI model can only be used when changing existing activities. When defining a scenario, it is best to depart from a contract to collect $\mathrm{x}$ ton (on an annual basis) from one or more waste producers. Each assignment consists of different journeys divided into duration and distance. Afterwards, the total duration and distance to be traveled can be calculated.

\section{Step 2: determination of the effects of the scenario on the parameters (1 per 1)}

When the most relevant parameters are known (step 0) and the scenario to be investigated is described as good as possible (step 1), step 2 assesses the scenario's effects on the different parameters. Each parameter is therefore assessed individually in a selfdeveloped Excel tool. Depending on the parameter, the evolution can be explained by: "higher/lower", "more/less", "wider/less wide". Each parameter is filled in by the assessor, based on own experience or on information collected at relevant stakeholders. In some cases, it is impossible to estimate this evolution, which is indicated by "No effect/ Non-Relevant (NR)". Clearly, the PI model is not drawn up from one party's vision in the logistics chain. The intention is always to estimate the effects for all possible parties, ranging from logistics service providers to shippers. A hypothetical example is shown in Fig. 5. 


\begin{tabular}{|c|c|c|}
\hline \multirow{9}{*}{$\begin{array}{l}\text { Characteristics } \\
\text { of logistics } \\
\text { (pick up and } \\
\text { collection) }\end{array}$} & \multirow{5}{*}{$\begin{array}{l}\text { Characteristics of the } \\
\text { collection area }\end{array}$} & Sunnly of uncto \\
\hline & & suppry or waste \\
\hline & & $\begin{array}{l}\text { Window times during which waste can be collected in } \\
\text { cities and municipalities } \\
\text { Possibility to collect waste at night } \\
\text { Size of pick-up area } \\
\text { Collection distance per trip } \\
\text { Possibility to bundle waste during a ride } \\
\text { Collection is mainly a point to point collection } \\
\text { Fine-meshed collection is necessary } \\
\text { Number of waste providers } \\
\text { Geographical concentration of supply and demand } \\
\text { Volumes to be retrieved are located in one place } \\
\text { Waste is collected in an urban or rural environment } \\
\text { Tonnage to be retrieved during assignment }\end{array}$ \\
\hline & & Demand for waste \\
\hline & & $\begin{array}{l}\text { Number of collection channels } \\
\text { Density of waste hubs and processing facilities } \\
\text { (including incinerators) } \\
\text { Number of collectors of waste }\end{array}$ \\
\hline & $\begin{array}{l}\text { Storage, } \\
\text { transshipment sorting } \\
\text { space attributes }\end{array}$ & $\begin{array}{l}\text { Need for additional transshipment movements of } \\
\text { waste } \\
\text { Availability of transshipment storage and sorting space } \\
\text { Cost of transshipment, storage and sorting space } \\
\text { (euro/year) }\end{array}$ \\
\hline & $\begin{array}{l}\text { Characteristics modal } \\
\text { choice of transport }\end{array}$ & $\begin{array}{l}\text { Need for pre- and/or post-transport when using inland } \\
\text { waterways or train } \\
\text { Frequency of service when using inland waterways or } \\
\text { train } \\
\text { Transport time per trip } \\
\text { Reliability of service when using inland waterways or } \\
\text { train } \\
\text { Flexibility of service when using inland waterways or } \\
\text { train } \\
\text { Safety when using inland waterways or train } \\
\text { Economies of scale when using inland waterways or } \\
\text { trains }\end{array}$ \\
\hline & \multirow[t]{2}{*}{$\begin{array}{l}\text { Fleet and technology } \\
\text { used }\end{array}$} & Vehicle characteristics \\
\hline & & $\begin{array}{l}\text { ICT systems used for routing } \\
\text { Depreciation value of the vehicle (EUR/ year) } \\
\text { Residual value of the vehicle (EUR/ vehicle) } \\
\text { Driver's staff costs (EUR/hour) } \\
\text { Taxes (traffic taxes, road charges, etc.) (EUR/year) } \\
\text { Insurance (EUR/ year) } \\
\text { Overhead (EUR/year) } \\
\text { Interest burden (EUR/ year) } \\
\text { Fuel cost (EUR/ liter or EUR/km) }\end{array}$ \\
\hline
\end{tabular}

Fig. 4 Different characteristics of the parameters explained. Source: Own composition

\section{Step 3: determining the joint effect of the changed parameters on the total logistics costs, waste treatment, and sustainability aspects}

After the individual effects of each parameter have been filled in, a qualitative assessment of the changed parameters on the total logistics costs, waste treatment and 


\begin{tabular}{|c|c|c|}
\hline & & $\begin{array}{l}\text { Average consumption (Quantity/ 100km) } \\
\text { Maintenance costs (EUR/year) } \\
\text { Distance travelled (per assignment) } \\
\text { Time travelled (per assignment) } \\
\text { Expected operating time per year } \\
\text { Expected distance travelled per year } \\
\text { Employability of the vehicle for other assignments } \\
\text { Number of journeys per assignment } \\
\text { Number of escorts required for transport }\end{array}$ \\
\hline & $\begin{array}{l}\text { Characteristics of the } \\
\text { location where the } \\
\text { collected waste is } \\
\text { treated and or } \\
\text { processed }\end{array}$ & $\begin{array}{l}\text { Infrastructure and resources needed to process waste } \\
\text { Total volumes of waste to be processed } \\
\text { Compatibility with current operation (in case new type } \\
\text { of waste is collected) } \\
\text { Necessary technological developments at the place of } \\
\text { processing }\end{array}$ \\
\hline & $\begin{array}{l}\text { Characteristics of } \\
\text { customers where } \\
\text { waste is collected }\end{array}$ & $\begin{array}{l}\text { Pick-up time at customer (window times) } \\
\text { Requested frequency of collection } \\
\text { Required customer presence at collection }\end{array}$ \\
\hline & $\begin{array}{l}\text { Type of load carriers } \\
\text { used }\end{array}$ & $\begin{array}{l}\text { Volume of cargo carrier used (e.g. container size) } \\
\text { Combinability of waste fractions in the transport carrier } \\
\text { Need for another type of load carrier }\end{array}$ \\
\hline & Regulations & $\begin{array}{l}\text { Waste transport } \\
\text { Introduced incentives to collect waste } \\
\text { Environmental surcharges } \\
\text { Necessary permits to transport waste } \\
\text { Training required to transport waste } \\
\text { Collection obligations of waste fractions } \\
\text { Application of the Major Act in the transport of waste } \\
\text { Presence of cross-border restrictions } \\
\text { Administrative burden due to transport of waste }\end{array}$ \\
\hline \multirow{6}{*}{$\begin{array}{l}\text { Characteristics } \\
\text { of waste }\end{array}$} & Recyclability & \\
\hline & $\begin{array}{l}\text { Combinability with } \\
\text { other goods }\end{array}$ & $\begin{array}{l}\text { Bundling different waste streams } \\
\text { Need to clean out load carrier } \\
\text { Extent to which waste can be compacted }\end{array}$ \\
\hline & Volume density & \\
\hline & $\begin{array}{l}\text { Continuous availability } \\
\text { of waste streams and } \\
\text { planning }\end{array}$ & \\
\hline & Dry versus wet waste & \\
\hline & $\begin{array}{l}\text { Possibility of storage } \\
\text { of waste }\end{array}$ & $\begin{array}{l}\text { Difference between value of waste and created raw } \\
\text { material (added value) } \\
\text { Consideration of alternative valorizations (costs/ } \\
\text { revenues) } \\
\text { Difference with classic price raw material }\end{array}$ \\
\hline
\end{tabular}

sustainability aspects must be made. To categorize these effects, Fig. 3 is used. It shows an overview of a number of typical, logistics waste processes in which the focus is on the generation of waste in Flanders. In Table 1, a distinction is made between three blocks (logistics, processing and sustainability). In the "logistics" block, an 


\begin{tabular}{|l|l|l|}
\hline \multirow{2}{*}{} & Purity \\
\cline { 1 - 2 } & Pre-sorting rate \\
\cline { 2 - 2 } & Waste treatment cost & \\
\cline { 2 - 2 } $\begin{array}{l}\text { Environment } \\
\text { and social } \\
\text { awareness }\end{array}$ & $\begin{array}{l}\text { Household awareness } \\
\text { (e.g. to recycle) } \\
\text { Awareness of product } \\
\text { design } \\
\text { Awareness of } \\
\text { packaging design } \\
\text { Awareness within } \\
\text { companies } \\
\text { Pressure from society } \\
\text { to change approach }\end{array}$ & \\
\hline \multirow{2}{*}{ Fig. 4 continued } & & \\
\hline
\end{tabular}

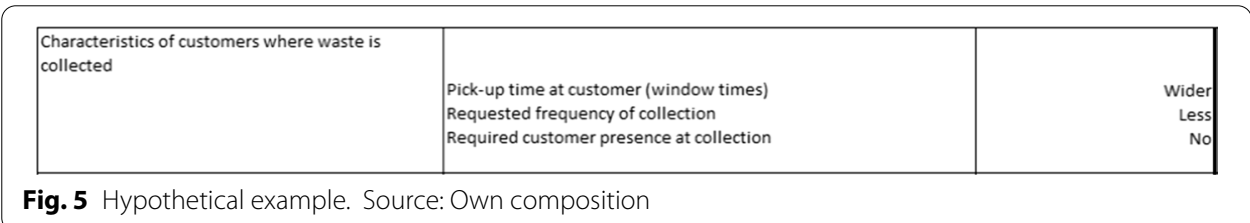

estimate is made of the effects on the logistics cost of the processes (from the point of view of different stakeholders), based on the exercise in Step 2. For each type of collection and stakeholder, an indication is made on how this changes the logistics cost. In the "processing" block, an analysis is given of the processing outcome on waste treatment, divided by type. Finally, sustainability effects can be assessed by indicating how raw material recovery and external costs occur. External costs are costs that the transport user causes for third parties without paying for it themselves.

\section{Applications to the framework}

The paper's PI model aims to take a deep dive into new initiatives within the waste logistics sector affecting the implementation of the circular economy. The emphasis is on introducing a logistics interpretation to ensure higher efficiency and/or effectiveness in the recovery, collection, and transport of various (secondary) material flows. Three projects were selected to go deeper, based on 1. economic feasibility, 2. practical feasibility within the project planning (e.g.: are people willing to participate in this?), 3. compliance with the project scope, 4 . relevance to the company in question, 5 . the degree of innovation and the potential for improvement, and 6. the leverage effect (or scale-up potential) for the Flemish logistics sector.

\section{Sensor technology on outlets and roll containers (telemetry)}

Telemetry is the remote measurement of parameters, with many applications in the context of waste logistics-i.e. filling rate of textile containers, glass spheres, semi-underground containers, Etc. Making predictions with the aid of telemetry, an assessment of whether a container needs to be emptied and/or collected can be made remotely. As a 


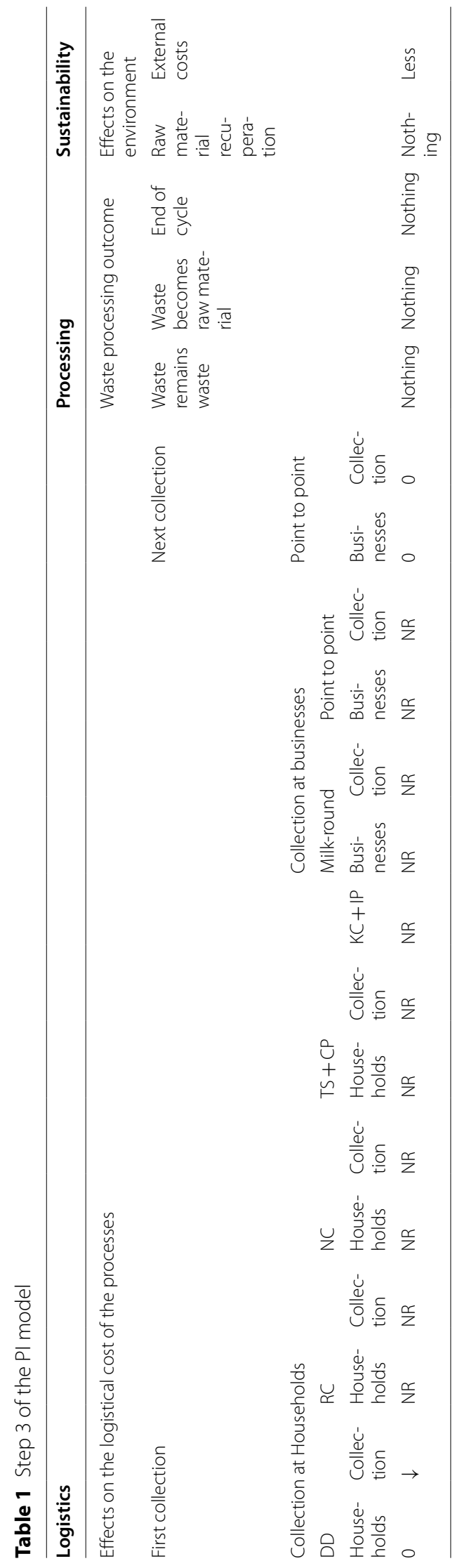



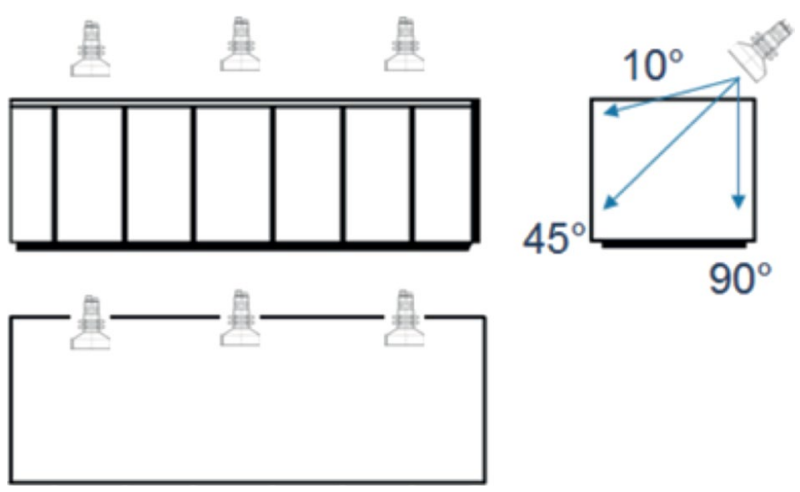

Fig. 6 Placement of ultrasonic sensors. Source: VIL

result, pick-up schedules are easily drawn up, and the customer no longer has to contact the waste company to collect full containers. The optimization takes place as the collector is able to create the most optimal routes based on the filling rate of the different containers. This is in contrast to today, where the containers are emptied by means of a fixed route independent of the filling rate-leading to unnecessary emptying and additional costs that are irrelevant and avoidable.

The filling degree can be measured using smart ultrasonic and/or infrared sensors (Fig. 6). Many of these sensors are already on the market offered by a multitude of providers, including Enevo, Smartbin, Sigrenea, and others. The great advantage of the ultrasonic sensor is that it can be used in an outdoor environment and that the measurement results are reliable for different types of waste. The open container with a volume of $30 \mathrm{~m}^{3}$ is the most common and used in this case. The measurements in the project were made using an ultrasonic and infrared multi-beam LED scanner-both from Pepperl + fuchs. The intention was to get an idea of the placement of the sensors and the amount of sensors needed to get good insights of the filling degree. When using ultrasonic sensors, three are required to get a good picture placed under an angle of $45^{\circ}$ (De Vylder et al. 2016).

The sensors can provide added value by predicting when a container is full. Remote containers, therefore, should not be emptied uselessly, bringing significant efficiency gains and no additional cleaning costs. When applying the scenario to the PI model, the following reference and alternative scenario can be formulated:

- H0: Containers (household waste) are collected according to a fixed schedule

- H1: The planning of the collection of the containers (household waste) is done according to the filling degree.

The following tables reflect the influence on the different variables and the correlating logistics costs.

Reflecting from Tables 2 and 3, it is clear that the telemetry usage only influences the logistics and sustainability part of the (reverse) waste chain, aiding to the efficiency of collection, leading to fuller trucks and fewer kilometers to be driven. This allows lowering the external cost caused by pollution of combustion engines used by trucks. 


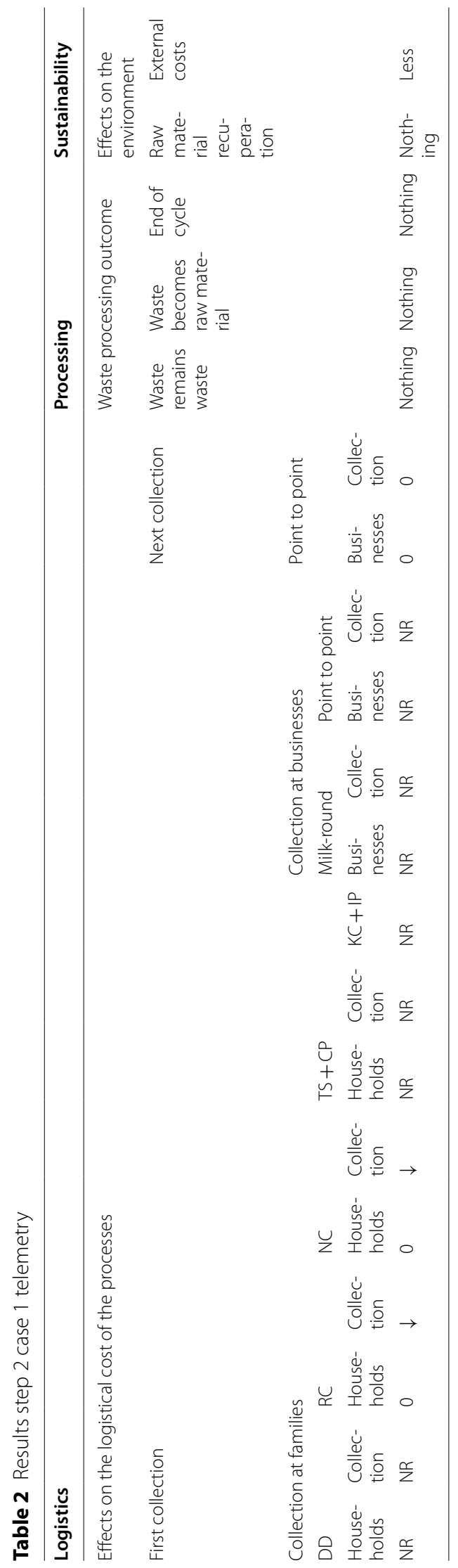


Table 3 Results step 3 case 1 telemetry

\begin{tabular}{|c|c|c|c|}
\hline \multicolumn{3}{|c|}{$\begin{array}{l}\text { Parameters that are important in the assessment of waste logistics and the associated } \\
\text { processes (step 0) }\end{array}$} & \multirow[t]{2}{*}{$\begin{array}{l}\text { Effects of the } \\
\text { scenario (step } \\
\text { 2) }\end{array}$} \\
\hline \multirow[t]{16}{*}{ Characteristics of logistics } & \multirow{4}{*}{$\begin{array}{l}\text { Characteristics of the pick-up } \\
\text { area }\end{array}$} & Supply of waste & \\
\hline & & Collection distance per ride & Smaller \\
\hline & & Possibilities for bundling & More \\
\hline & & $\begin{array}{l}\text { Fine-meshed collection is } \\
\text { necessary }\end{array}$ & Less \\
\hline & $\begin{array}{l}\text { Characteristics of storage trans- } \\
\text { shipment and sorting space }\end{array}$ & Demand of waste & \\
\hline & $\begin{array}{l}\text { Characteristics mode of trans- } \\
\text { port }\end{array}$ & & \\
\hline & \multirow[t]{6}{*}{ Fleet and technology used } & Vehicle characteristics & \\
\hline & & ICT systems used for routing & More \\
\hline & & Average consumption (/100 km) & Higher \\
\hline & & $\begin{array}{l}\text { Distance travelled (per assign- } \\
\text { ment) }\end{array}$ & Lower \\
\hline & & Time travelled (per assignment) & Lower \\
\hline & & $\begin{array}{l}\text { Vehicle's usability for other } \\
\text { contracts }\end{array}$ & Higher \\
\hline & $\begin{array}{l}\text { Characteristics of the location } \\
\text { where the collected waste is } \\
\text { treated/ processed }\end{array}$ & & \\
\hline & $\begin{array}{l}\text { Features customers where the } \\
\text { waste is collected }\end{array}$ & $\begin{array}{l}\text { Demanded frequency of col- } \\
\text { lection }\end{array}$ & Less \\
\hline & Type of cargo carriers used & & \\
\hline & Regulation & & \\
\hline
\end{tabular}

Table 3 shows that the collection distance per trip is smaller, because of more efficient routing (avoiding redundant trips). On the other hand, extra stops can be included that were not possible if telemetry is not used (more bundling possibilities). Less fine-meshed collection is the consequence. The average consumption is assessed to be higher, because of a higher filling rate of the vehicle.

\section{Small waste compactors}

Waste compactors are hydraulic or electric presses that use mechanical force to reduce the generated waste's volume to weight ratio. Usually, the results are the biggest with waste that has a low material density, such as cardboard, paper, plastics, metal etc. (Mil-tek, sd). The most significant advantage is that waste compactors can be small enough to be installed at the point of collection-i.e. stores or other businesses. Enabling to optimize the restricted load capacity-of a garbage truck-and thus also optimizing routing and stops. Two different waste compactors can be distinguished by type: 1 . vertical balers and 2 . horizontal balers. Vertical balers use horizontal force to press waste and are usually bigger in size (used at recycling centers). Horizontal balers use vertical force to press waste together and are more often used at pick-up points. By using a compactor on the business side, the customer's waste no longer has a negative value, and the latter can receive a fee since the collector has to carry out fewer trips. The focus is on the compacting of waste at the place of 


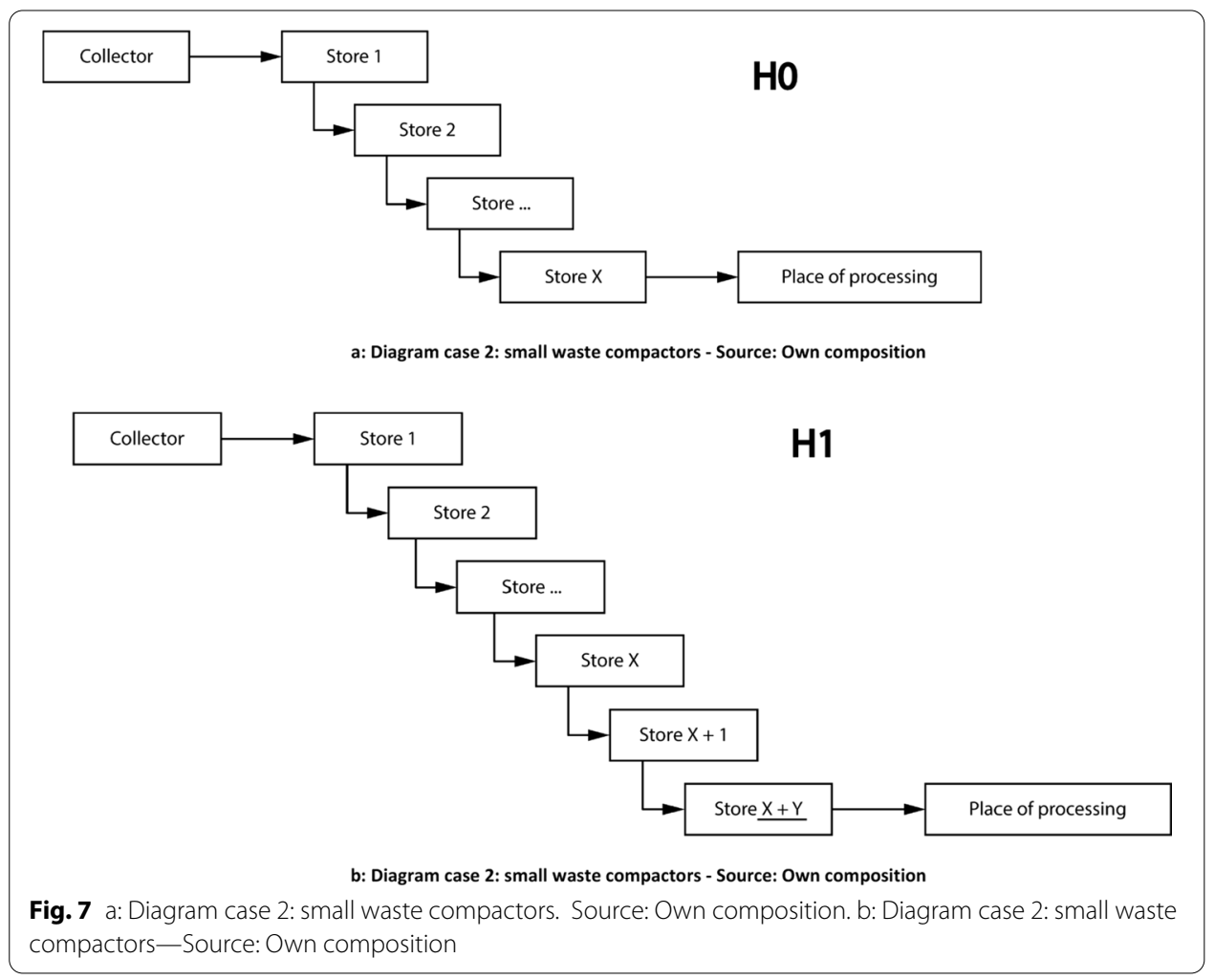

production. By compacting waste, it becomes possible to transport more tonnage per volume as compared to not using a waste compactor. The reference scenario and the alternative scenario for the PI-model can be formulated as follows:

- H0: Waste is not compiled in the first place of collection (company waste)

- H1: Waste is compiled in the first place of collection (company waste)

Derived from Fig. 7, it is clear that using a waste compactor makes it possible to collect waste from a bigger collective of pick-up points.

Table 4 clarifies that there are only changes in the logistics part of the business waste chain. Only businesses have enough cardboard and paper waste to use a waste compactor. As with the usage of telemetry, the need for extra trips is reduced due to an increase in the tonnage-to-volume ratio. For indoor waste compactors, this volume reduction can range from a 10 to one ratio up to a 15 to one ratio depending on the type of compacted waste. Resulting in a potential 10/1 lowering of trips needed. Always taking into account the weight limitations of the trucks used. (Kennedy, sd). This in turn leads to a reduction of emissions caused by combustion engines and is reflected by a decrease in external costs. Note that implementing a waste compactor leads to a decrease in logistics costs for the collection company and a potential cost increase for the collection points at the business side (investment in waste compactor). 


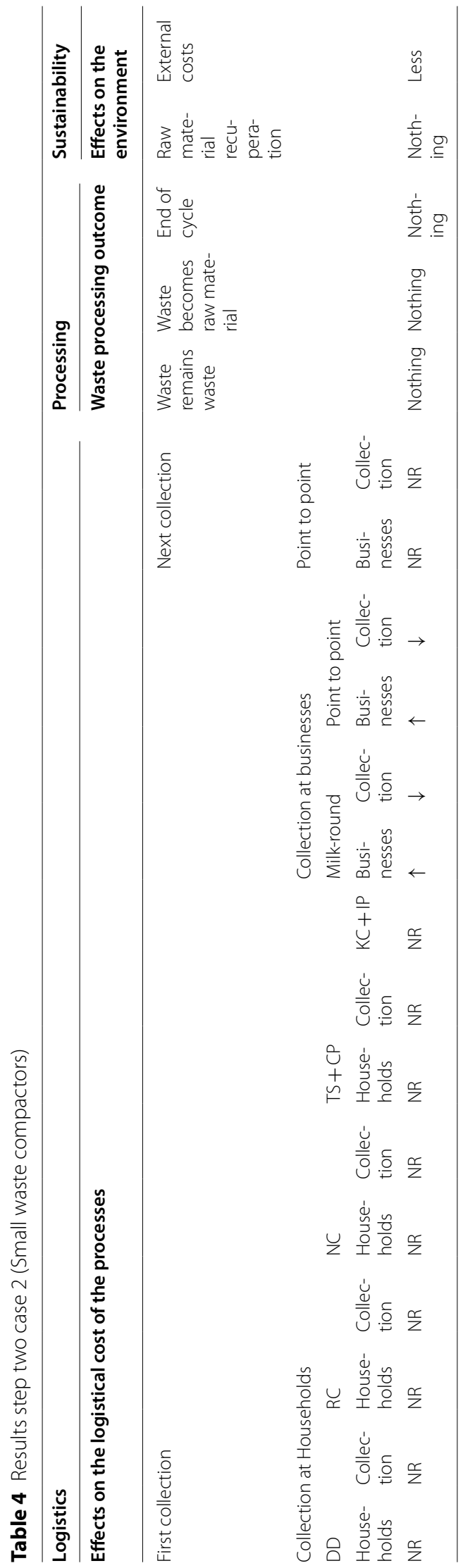




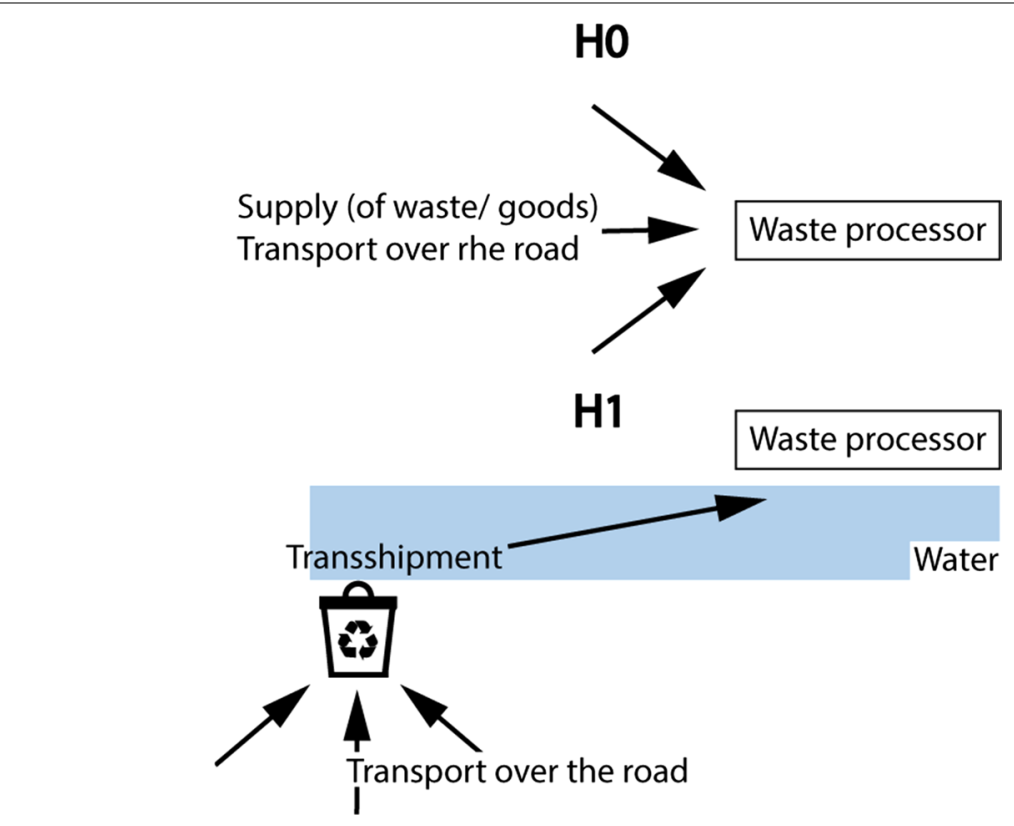

Fig. 8 Representation of transport over water. Source: Own composition

Table 5 Results step 3 case 2 (Waste compactor)

Parameters that are important in the assessment of waste logistics and the associated processes (step 0)

2)

Characteristics of logistics

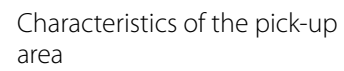

Supply of waste

More

Collection distance per ridepossibilities for bundling

Demand of waste

Characteristics of storage transshipment and sorting space

Availability of transshipment/ More storage / sorting space

Characteristics choice of mode of transport

Fleet and technology used

Vehicle features

Distance travelled (per assign- Lower ment)

Time travelled (per assign- Lower ment)

Vehicle deployment possibili- Higher ties for other routes

Number of routes per assign- Less ment

Characteristics of the location where the collected waste is treated/ processed

Features of the customers where the waste is collected

Requested frequency of col- Less lection

Type of cargo carriers used

Regulation

Ton/ $\mathrm{m}^{3}$ 
Table 5 represents the different parameters that are impacted due to the implementation of a waste compactor. Clearly stating a boost in efficiency of the logistics side and an increase in waste density.

\section{Modal shift-waste over water}

With an increasingly pressing problem of waste, congestion, and the environment, the logical consequence is to look for alternative modes of transport. Inland waterway and rail transport meet the conditions and can be used perfectly for the transport of waste-and in particular residual waste. An overview of this process can be found in Fig. 8. The flows are large enough to enjoy the economies of scale. Therefore, this application aims to verify whether it is interesting to work out a business case to transport residual waste by water if the shipper and the recipient are located alongside the water. It is crucial as additional steps in the supply chain come at a high cost. Specifically, the last mile is very cost-intensive.

The reference scenario and the alternative scenario are formulated as follows:

- H0: The waste treatment plant is not next to the water. Only road transport is used for the supply of waste.

- H1: The waste treatment plant is located next to the water. The supply of waste is done as much as possible with inland shipping.

In the PI-analysis carried out, the focus is on transport via road. In HO, waste is collected at several collection points and transported directly to the waste processor. Whereas in $\mathrm{H} 1$, waste is collected at several collection points and transported to a transshipment location. Based on the PI analysis, one might conclude that road transport becomes cheaper, and the success of $\mathrm{H} 1$ will depend on the extra cost of inland navigation. Therefore, the lessons learned from the IOK case can be used.

The effects on road transport are straightforward (Table 6). Truck distances will be reduced because the transshipment location is closer than the actual distance to the waste processor. In case inland navigation is used, bundling is the direct effect. An extra transshipment point is included (density of waste hubs and processing facilities), incurring additional CAPEX (Capital Expenses) and OPEX (Operational Expenses). It is evident that the costs related to trucks will be lower than in the case of direct transport $(\mathrm{HO})$. Whether or not this case will be interesting will depend on the extra cost of using inland navigation (transshipment infrastructure and costs).

Using inland waterways can lower costs for the collection side since economies of scale are favorable and attainable under the right conditions-i.e., location, terminal, equipment, consolidation point, type of waste, etc. (De Vylder et al. 2016). Nevertheless, the solution does not influence the processing or sustainability aspect of the waste chain. Though it is clear that the usage of inland waterways results in a reduction of external cost-i.e., lower emission per ton-and is reflected in Table 7.

The intercommunal development company for the Kempen (IOK) collects all residual waste from the region that undergoes mechanical recycling, drying, and filtering. What remains is Refuse-Derived Fuel (RDF), a commodity that sits on the boundary between waste and fuel. Due to the negative value, the IOK has to pay for the 


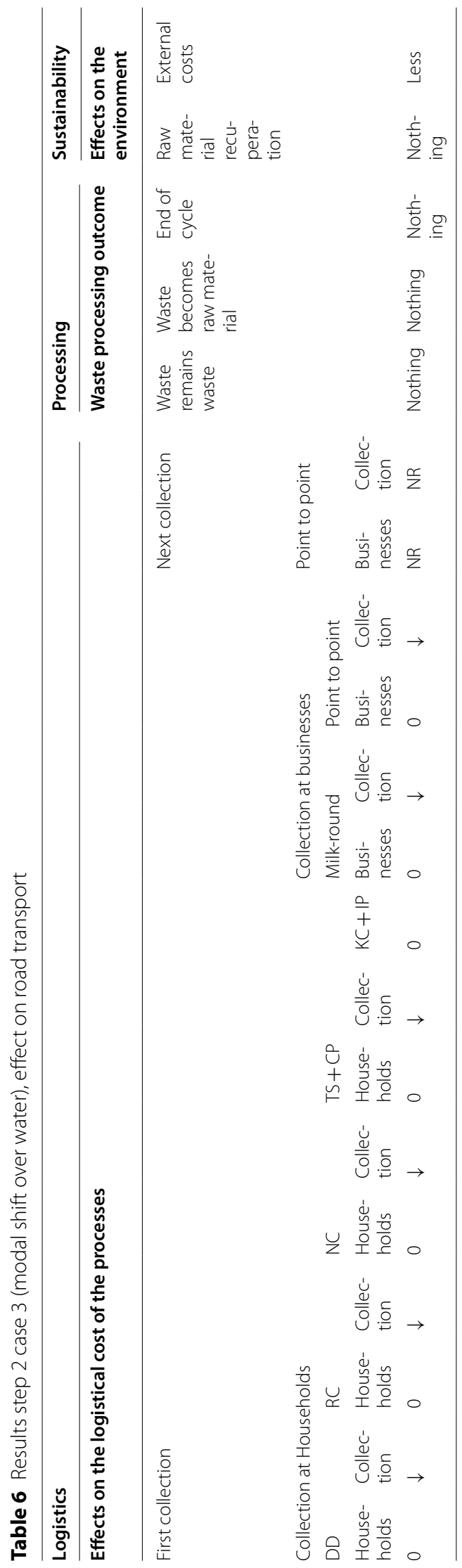


Table 7 Results step 3 case 3 (modal shift over water)

\begin{tabular}{|c|c|c|c|}
\hline \multicolumn{3}{|c|}{$\begin{array}{l}\text { Parameters that are important in the assessment of waste logistics and the associated } \\
\text { processes (step 0) }\end{array}$} & \multirow[t]{2}{*}{$\begin{array}{l}\text { Effects of the } \\
\text { scenario (step } \\
\text { 2) }\end{array}$} \\
\hline Characteristics of logistics & Characteristics of the pick-up & Supply of waste & \\
\hline & & $\begin{array}{l}\text { Collection distance per ride- } \\
\text { possibilities for bundling }\end{array}$ & Lower \\
\hline & & Demand of waste & \\
\hline & & $\begin{array}{l}\text { Density of waste hubs and } \\
\text { processing facilities (including } \\
\text { incinerators) }\end{array}$ & More \\
\hline & $\begin{array}{l}\text { Characteristics of storage } \\
\text { transshipment and sorting }\end{array}$ & $\begin{array}{l}\text { Need for additional transship- } \\
\text { ment movements of waste }\end{array}$ & More \\
\hline & space & $\begin{array}{l}\text { Availability of transshipment, } \\
\text { storage and sorting space }\end{array}$ & More \\
\hline & & $\begin{array}{l}\text { Cost of transshipment, stor- } \\
\text { age and sorting space }\end{array}$ & Higher \\
\hline & $\begin{array}{l}\text { Characteristics choice of } \\
\text { mode of transport }\end{array}$ & & \\
\hline & Fleet and technology used & Vehicle features & \\
\hline & & $\begin{array}{l}\text { Distance travelled (per assign- } \\
\text { ment) }\end{array}$ & Lower \\
\hline & & $\begin{array}{l}\text { Time travelled (per assign- } \\
\text { ment) }\end{array}$ & Lower \\
\hline & & $\begin{array}{l}\text { Vehicle deployment possibili- } \\
\text { ties for other routes }\end{array}$ & Higher \\
\hline & $\begin{array}{l}\text { Characteristics of the location } \\
\text { where the collected waste is } \\
\text { treated/processed }\end{array}$ & & \\
\hline & $\begin{array}{l}\text { Features of the customers } \\
\text { where the waste is collected }\end{array}$ & & \\
\hline & Type of cargo carriers used & & \\
\hline & Regulation & & \\
\hline \multicolumn{4}{|l|}{ Characteristics of waste } \\
\hline \multicolumn{4}{|l|}{$\begin{array}{l}\text { Environmental and social } \\
\text { awareness }\end{array}$} \\
\hline Other effects & & & \\
\hline
\end{tabular}

processing of this RDF by other companies. One such company is the Stora Enso paper mill located in Ghent. Although both are located alongside the water, only road transport is used due to historical evolution, favorable rates, and the paper mill does not prefer to have too much stock of RDF because of its highly flammable character. Table 8 reflects the cost index of different scenarios of transport of RDF from the intercommunal development company to Stora Enso.

It is clear that even when both companies are located on the water, road transport is still favorable in terms of costs. The costs depend on the type of goods transported and the preconditions for the transport to be fulfilled. 
Table 8 Cost index of road transport versus inland shipping solutions. Source: (De Vylder et al., 2016)

\begin{tabular}{ll}
\hline Transport price per ton (relative representation) & \\
\hline Road transport 2016 incl. kilometer charge & 100 (= basis) \\
Inland shipping containers -1 departure per week (700 ton) with purchased reach stacker & 102 \\
Inland shipping bulk -1 departure per week (700 tons) & 115 \\
Inland shipping containers -1 departure per week (700 tons) with rented reach stacker & 116 \\
Inland shipping bulk—-2 departures per week (350 tons per departure) & 123 \\
Inland navigation bales-1 departure per 10 days (1.000 tons) & 124 \\
Inland navigation bales -1 departure per week (700 tons) & 140
\end{tabular}

\section{Conclusion}

More and more importance is being attached to sustainability and corporate social responsibility. Reflecting in new production processes and expanding logistics activities-i.e., waste logistics. The latter in particular is essential and is often overlooked. In many cases, it is technically possible to work via the principles of "cradle to cradle", but often the logistics side and its correlating costs of the supply chain are forgotten. As long as it is impossible to organize the supply chain logistics sustainably and efficiently, the "cradle to cradle" model is not feasible. Often the problem is the fact that the waste market is very fragmented. Requiring a lot of sunk costs to create large volumes-and thus economies of scale-to reduce the unit cost. It is important to remember that when volumes are large enough, rail and water transport can be perfect substitutes, considering that both parties need to be located at the waterfront and/or rail since additional transshipments are expensive, as is last-mile delivery. The applicability of rail and inland waterway transport is partly facilitated by the non-time-critical character of waste and no need for short lead times. Sensors can form a viable application for those containers that are hard to reach and thus costly to empty. Reflecting in a net positive business case resulting in lower emissions and lower collection costs. Utilizing waste compactors at businesses positively impacts reverse logistics, enlarging the weight to volume ratio of residual products/waste with a low material density. Affecting the load capabilities of collection vehicles, reducing the need for extra trips, leading to a positive effect from a sustainability point of view.

Even though this paper only discusses three different applications, a lot more can be implemented, establishing a base for further research. Shortcomings of the model can be that the qualitative assessment does not reflect all the potential restrictions of waste logistics innovations since the parameters enumerated in Fig. 4 are not inclusive. Resulting in the inability to use the model within specific scenarios. Nevertheless, the model can be updated and adjusted to the ever-changing variety of innovations. Thus, reflecting a learning curve over time, adding new/additional parameters to become a multipurpose model. Additionally, it should be emphasized that the PI model is a qualitative model to assess different waste scenarios rather direct without the need for additional information. Giving the first insight into the feasibility of the waste logistics scenario. 
Annex: external participants stakeholder workshops.

\begin{tabular}{|c|c|}
\hline Coeck & Thomas Coeck \\
\hline Contraload & Jesse Sels \\
\hline nv De Scheepvaart & Gert Peeters \\
\hline Derbigum/Imperbel & Koen Sneiders \\
\hline Desso & Kirsten Rutten \\
\hline Gyproc & Tom Rommens \\
\hline \multirow[t]{2}{*}{ Infrabel } & Geert Mels \\
\hline & Geert Robbroeckx \\
\hline \multirow[t]{2}{*}{ Komosie } & Fred Goossens \\
\hline & Ivan Roelands \\
\hline \multirow[t]{2}{*}{ POM Oost-Vlaanderen } & Danny Vanrijkel \\
\hline & Maarten Manhaeve \\
\hline Siemens & Denny Decorte \\
\hline Shipit & Jan D’Haeyer \\
\hline \multirow[t]{2}{*}{ SITA } & Filip De Breucker \\
\hline & Peter Bevers \\
\hline The Brussels Airport Company & Christel Vandenhouten \\
\hline \multirow[t]{2}{*}{ Unilever } & Jannie van Andel \\
\hline & Karen De Sitter \\
\hline Van Heede Environmental logistics & Koen Smits \\
\hline Van Moer Group & Dennie Lockefeer \\
\hline
\end{tabular}

\section{Abbreviations}

CAPEX: Capital expenses; CSR: Corporate social responsibility; CP: Collection point; DD: Door-to-door; EPR: Extended producer responsibility; LCA: Life cycle assessment; NC: Neighborhood collection; NGO: Non-governmental organization; NR: Non-relevant; OPEX: Operational expenses; PI: Parameter impact; RC: Recycling center; RDF: Refuse-derived-fuel.

\section{Acknowledgements}

We would like to thank VIL for the financial support and additional contributions given during the project's execution. Without this contribution, the development of the parameter impact model would not have been possible. VIL's ILSE project proved to be very helpful in the development of this paper. The authors wish to also explicitly thank the participants to the four stakeholder workshops that were held.

\section{Authors' contributions}

TP conducted the main analyses in the study, with support by EV, and under supervision by TV. SS took care of company inputs and validation of results. JW conducted the writing of the report. All the authors read and approved the final manuscript.

\section{Funding}

This paper results from a study conducted under contract A13/0328 — Vlaams Instituut voor de Logistiek vzW: Innovative Logistics in waste management for a Sustainable Environment (ILSE). The contract stipulated the design of the study.

\section{Availability of data and materials}

The dataset analyzed during the current study is available in the EUROSTAT repository, Statistics|Eurostat (europa.eu)

Data sharing is not applicable to this article as no datasets were generated during the current study.

\section{Declarations}

\section{Competing interests}

Not applicable.

Author details

${ }^{1}$ University of Antwerp, Prinsstraat 13, 2000 Antwerpen, Belgium. ${ }^{2}$ POM Oost-Vlaanderen, Woodrow Wilsonplein 2, 9000 Gent, Belgium. ${ }^{3}$ VIL, Koninklijkelaan 76, 2600 Berchem, Belgium.

Received: 10 November 2021 Accepted: 28 January 2022

Published online: 23 February 2022 


\section{References}

Bluevision (n.d.) Infographic: how does the proces of mechanical recycling work? Retrieved from bluevision: https://bluev isionbraskem.com/en/intelligence/infographic-how-does-the-process-of-mechanical-recycling-work/

Borbon-Galvez Y, Curi S, Dallari F, Ghiringhelli G (2021) International industrial symbiosis: cross-border management of aggregates and construction and demolition waste between Italy and Switzerland.

Cyrkl (2021) Retrieved from https://www.cyrkl.com/en/

De Vylder D, D'Halleweyn A, Geysels L, Pauwels T, Sel S, Sys L, Vandenborre H, Vanelslander T (2016) Innovative logistics in waste management for a sustainable environment. VIL, Berchem

Emis (n.d.) Materiaalrecyclage: papier en karton. Retrieved from emisc: AFSS—afval mest verwerkingsselectiesysteem: https://afss.emis.vito.be/techniek/materiaalrecyclage-papier-en-karton

EUROSTAT (2021) Treatment of waste by waste category, hazardousness and waste management operations. EU.

Gelder R (2021) Waste matching platforms: data readiness_Stakeholder readiness_-Solution readiness. J. Willems, Interviewer

Gevaers R, Sys C, Vanelslander T (2012) Karakterisiteken van binnenlandse afvallogistiek in een innovatieve context. Antwerpen.

Hole G, Hole SA (2020) Improving recycling of textiles based on lessons from policies for other recyclable materials: a minireview. Sustain Prod Consump 42-51

International synergies (n.d.) National Industrial Symbiosis Programme. Retrieved from International synergies: https:// www.international-synergies.com/projects/national-industrial-symbiosis-programme/

Kennedy M (n.d.) Waste compactors—reduce the trash burden. Retrieved from Wastecare Corporation: https://www. wastecare.com/Articles/waste-compactors-reduce-the-trash-burden.htm

Kenton W, James M (2021) Greenwashing. Retrieved from Investopedia: https://www.investopedia.com/terms/g/green washing.asp

Makarichi L, Techato K-a, Jutidamrongphan W (2018) Material flow analysis as a support tool for multi-criteria analysis in solid waste management decision-making. Resour Conserv Recycl 351—365

Michail A (2021) Waste matching platforms: Data readiness—Stakeholder readiness—solution readiness. J. Willems, Interviewer

Milios L, Beqiri B, Katherine AW, Simon HJ (2019) Sailing towards a circular economy: conditions for increased reuse and remanufacturing in the scandinavian maritime sector. J Clean Prod 227-235

Mil-tek (n.d.) Soorten afval. Retrieved from Mil-tek: https://nl.miltek.be/soorten-afval/

OVAM (2019) Bedrijfsafval en secundaire grondstoffen productiejaar 2004-2018. OVAM

OVAM (2020) Jaarverslag 2020

Plastics Europe (n.d.) Recycling and energy recovery. Retrieved from PlasticEurope: https://www.plasticseurope.org/en/ focus-areas/circular-economy/zero-plastics-landfill/recycling-and-energy-recovery

Quidousse V (2021) Waste matching platforms: data readiness—Stakeholder readiness_-solution readiness. J. Willems, Interviewer

Reloop (2020) Who is reloop? Retrieved from Reloop: https://www.reloopplatform.org/about/

Sathish T, Jayaprakash J (2017) Optimizing supply chain in reverse logistics. Transstellar.

Seroka-Stolka O, Ociepa-Kubicka A (2018) Green logistics and circular economy. Transp Res Procedia 471-479

Suzanne E, Absi N, Borodin V (2020) Towards circular economy in production planning: challenges and opportunities. Eur J Oper Res 168-190

van den Bergh J (2020) Six policy perspectives on the future of a semi-circular economy. Resour Conserv Recycl

Van Dyck B (2008) Reststromen in de Gentse kanaalzone - onderzoek naar mogelijkheden voor uitwisseling en valorisatie. Gent.

VIL (2020) CiloTEX: Circulaire logistiek voor de textielsector. VIL, Antwerp

Visser PD (Director) (2018) Closing the loop—full film [Motion Picture].

Zero waste Europe (2018) Changing trends in plastic waste trade - Plastic Waste shipments report. Zero waste Europe

\section{Publisher's Note}

Springer Nature remains neutral with regard to jurisdictional claims in published maps and institutional affiliations. 